\title{
COLIN MICHAEL WELLS
}

(November 15, 1933-March 11, 2010)

\section{by Joann Freed and Mark B. Garrison}

Colin Wells was educated at Nottingham High School, where he often felt compelled to disguise his intelligence but nevertheless received an excellent grounding in Latin and Greek. Sports, especially cricket (a lifelong interest), gave him a feeling of belonging. He converted to Catholicism as a very young man and it always shaped his decision-making. He took his undergraduate Classical education at Oxford, having P. A. Brunt as tutor. At age 19 he lost his mother to cancer and took a break from university for military service (1954-56). Posted to Alexandria for a time, his most memorable experiences involved the challenges of horseback riding. A military career was his first choice, but a spot on his lung robbed him of that possibility. He met Kate, his wife of 50 years, when her family hired him as a boat boy for the summer in Wales. He admired and sympathized with Kate's father, author Richard Hughes, who, after early success with A High Wind in Jamaica (1929), often suffered from writer's block. When Colin finished his Oxford degree he had no idea of becoming an academic, but Coats' offer of a good salary to become a chartered accountant horrified him. His first post was teaching the sixth form at Beaumont College, but he was soon offered a job teaching Classics at the University of Ottawa. Kate agreed to go to Canada at once, and in 1960 the two were married. Although settling happily in Canada, Colin still considered Oxford "the centre of his world" when we first met him in the late 1970s.

In 1960, the University of Ottawa was an independent bilingual Catholic university. Colin's excellent French was key to his employment. His former student Hélène Leclerc said how shocked she was to hear him call the Late Roman skeleton she was excavating at Carthage "la maudite squelette"; his French was so impeccable that he had never before made a mistake in gender in her hearing. Colin was mentored by Father E. Gareau, founder and chair of the Classics department. At the time Ottawa had few faculty members with a doctorate and Gareau suggested that Colin return to Oxford for his degree. Meanwhile Kate became pregnant with Christopher, and Dominic was born while they were in Oxford (1962-64). At Oxford, with I. A. Richmond as his thesis advisor, Colin wrote a broader treatment of the foreign policy of the emperor than would be included in his first book (The German policy of Augustus [1972]). Colin was a historian first, with both excellent training and instincts in the use of archaeological evidence. In 1965 he was granted his doctorate.

Colin and Kate returned to Ottawa at a time of transition for the University, which in 1965 gave up its Catholic confessional status in order to receive public funding. This was an exciting year as $A$ High Wind in Jamaica was made into a film. Colin was intensely involved with his academic and administrative career and became editor of a journal recently founded at Ottawa, Echos du Monde Classique/Classical News and Views (now renamed Mouseion), a post he filled until 1981. His first article, in 1961, was a review of the Latin translation Winnie ille Pu. He wrote a share of the early issues he edited and contributed much to the journal's ultimate success. He served as Chair of his department from 1967 to 1972 and became a full professor in 1971. As Vice-Dean of the Faculty of Arts he participated in a Student Peace Conference with John Lennon and Yoko Ono (June 1969), a fact he rarely divulged. In the early 1970s Colin and Kate sent their boys to England for their education, but they missed having the children at home. After serving as a Visiting Lecturer in Archaeology at Brasenose College in 1973/74, he hoped to return to Oxford and his intellectual support system there.

In the 1960s Colin published little of his own work, but the overwhelmingly positive response from the academic world for The German policy of Augustus changed this. From this point he regularly published on his favoured topics: the Roman frontier (particularly the German), the Roman army, and the red sigillatas of Italy and S France held equal place with topics related to Carthage. He was tremendously productive between 1977 and 1983, codirecting the excavation of the Second Canadian Team at Carthage with E. M. Wightman. He published archaeological reports in Echos from 1977 to 1982 and again in 1988, and in the Carthage CEDAC Bulletin. He also wrote his successful overview, The Roman Empire (1984), which, after a long experience of teaching on this period, practically flowed off his pen fully 
formed. He always regarded reviewing as an important service to the profession, and other services multiplied. A member of the common room at Brasenose from 1974, he was elected a Fellow of the Society of Antiquaries in the same year.

Colin was an excellent and inspiring teacher, an expert on the Roman Empire and golden-age Latin literature. His graduate seminars on the Roman frontier were a staple of the department; on hearing that Colin might be leaving Ottawa in 1987, J. Thorp, then Chair, was horrified at the thought of losing "our best lecturer". Colin was mentor and friend to his graduate students, of whom he had a significant number at Ottawa in the mid-1980s, gently influencing them to do excellent work.

In 1975-76 Colin and Wightman were invited to participate in the SSHRCC-sponsored Canadian project at Carthage, part of the larger UNESCO project. Although not then a field archaeologist, Colin's critical success with the German policy of Augustus made him the most distinguished scholar in Canada with a knowledge of Roman archaeology. Attracted by the international distinction of the project, he welcomed the challenge. While not on the frontiers of the Roman empire (his lifelong interest), Carthage did become a walled city in A.D. 425, and the Second Canadian Team was assigned a large tract of land along decumanus VI north that included a stretch of the Teurf el-Sour, an embankment marking the line of the Theodosian Wall. With his fluent French, charm and gentlemanly demeanor, Colin made the necessary contacts in Tunisia with unusual ease, considering "bonhomie" a useful personal skill. He genuinely liked those he worked with in Tunisia, respecting particularly Abdelmajid and Liliane Ennabli. He brought S. Lancel, one of the directors of the French team, to Ottawa for a year in the mid-1980s; on the other hand, he and Québec separatist P. Senay, head of the First Canadian Team, tended to avoid each other.

The Second Canadian team first came to Carthage for a 5-week season in 1976, returning for a study season in 1977. Working with the brilliant but acerbic E. M. Wightman was a challenge for Colin. Physically they were an odd pair, as she was over 6 feet tall and Colin was short, but in fact they divided up the work so that each worked independently. In the first season they found what they were looking for, both the robber trench of the Theodosian Wall and evidence for the intersection of decumanus VI north and cardo III. In 1978 the team returned for excavation and field survey with student supervisors from Ottawa and McMaster. This season revealed detail about the city wall, the street system, and the houses inside the wall. In the main trench (2CC1-2) finds included a large deposit of mid-5th c. pottery, dumped where the Wall blocked decumanus VI north (Neuru 1980). In 1979 Wightman found a rectangular tower (the first Wall tower excavated at Carthage) in trench 2CC7. In 1980 a massive Roman opus africanum wall, cut down to ground level, was found on the exterior side of the city wall. He continued with campaigns in 1981, 1982 and 1983, returning for follow-up work in 1985 and 1986. All these seasons focused on the Theodosian Wall and the structures on either side of it, including the Roman houses inside. Preliminary reports were supplemented by articles on special questions, particularly on the defense of Carthage. Being keen to keep Echos a bilingual journal, he wrote two early articles on the site in French. By 1988 more than 25 contributions dealt with the excavations of this site, the majority written by Colin himself.

Carthage for Colin meant 21 rue Kennedy, the second floor of which Colin regularly rented to house his team. This large house lay a few blocks south and east of where the ancient decumanus maximus and cardo maximus intersected on the Byrsa hill. A balcony running the full length of the house looked out towards the peak of Bou Kornine across the Gulf of Tunis. The tram line, supermarket and cafes were close by. The National Museum, where pottery and finds were registered, was close by, and the excavation site was within walking distance. Colin had the small end room as bedroom and office, while two large rooms at either end housed male and female team members, respectively. The physical layout encouraged communication between team members and director, and Colin had a natural talent for organizing a homey atmosphere; although as many as 14 people filled the house, people felt comfortable and rarely got sick.

The murder at McMaster University (1983) of E. M. Wightman was a terrible shock to the team. Simultaneously Colin experienced other personal blows. Struggling to maintain the appearance of normality, he became a difficult colleague. While retaining many friends and 
supporters, such as S. Treggiari, from 1984 to 1987 it was impossible for him to concentrate on Carthage. Then E. Neilsen of Trinity University in San Antonio encouraged Colin to apply for the T. Frank Murchison Distinguished Professorship in Classical Studies. Performing brilliantly in the job interview, he was offered the opportunity to build an undergraduate classics program with an emphasis on history and archaeology, aspects which he felt were threatened at Ottawa. He left Canada for San Antonio in 1987, imagining that he was also abandoning Carthage. He took up the new challenges with vigor, hiring new faculty and establishing a curriculum. When M. Garrison came to Trinity in 1989, there was already great excitement on campus for the new program and a core of enthusiastic majors. While chair of Classical Studies and a member of the history department, Colin taught a wide range of courses, including introductory surveys in Greek and Roman history and advanced courses on the Roman Empire and army, the archaeology of North Africa, and Greek and Latin literature. He became a mentor to younger faculty, and the many gatherings that he and Kate hosted at home, often centered around music, were legendary. He left a lasting imprint on many student majors and the department that he founded remains one of the strongest at Trinity University. While at Trinity he continued to write papers and reviews and revised his book on the Roman Empire. He coordinated work on the maps of N Africa and central Europe for the Barrington Atlas edited by R. J. A. Talbert. He also presented several conference papers (unpublished) on the political history of archaeology in N Africa while continuing to attend favorite congresses, especially the LimesCongress. In 2002 he became President of the Fautores and was one of the editors of the Conspectus (1990), satisfying his long interest in Italian red gloss wares and their imitations.

But Carthage remained one of the most interesting opportunities open to Colin. The zone originally assigned to the Second Canadian Team extended east of the original dig site, passing along the side of the Odeon. By 1990 Colin and Garrison planned a campaign on the Odeon Hill, with students from Trinity participating in a field school. The first object was a large bathhouse on the S side of decumanus VI north, first discovered by Wightman in 1978 (area 2CC6). A major goal was to clarify the water supply to the hill, which lay above the level of the city's aqueduct. Later in the 1990s Colin worked with E. Haldenby (University of Waterloo) on the site and plan of the Odeon itself, with students from both universities. Colin researched the history of earlier excavation of the Odeon by P. Gauckler (Wells 1996). The Odeon excavations were limited in relation to the massive size of the site, but in the 1996 season M. Carroll and D. Godden worked with Colin on a well-stratified section of decumanus VI north, quickly published by JRA (1998); Colin also wrote on the Odeon site in AJAH (2004).

Colin was born into a conservative milieu and taught a conservative discipline. Although he caught the wave of enthusiasm for archaeology, he resisted adaptation to the fast-moving changes of the second half of the 20th c. (for example, in the rôle of women, or the ubiquity of computers). He could be fair-minded if he was not already committed, but his first response was always emotional and conservative. What he called "deep structures" were crucial to him: family and home, Oxford and its intellectual traditions, and the teachings of the Catholic Church. By 2006 he had been involved in excavation and publication at Carthage for three decades, but he never organized a final report for his sites. A competitive person, he hesitated to publish where he could not meet a high standard: events repeatedly thwarted him, and he would not complete a final report without his ideal team.

Following retirement, Colin and Kate returned to Oxford, but later moved to a large farmstead in Normandy with room for entertaining as well as for Colin's many books. A brilliant man with a wide range of interests and innumerable friends spread over more than two continents, he was enjoying a busy and stimulating life. Although he died too young, by the time of his retirement he had spent 45 years as an academic and scholar. In an obituary (April 28, 2010) the Sunday Times listed achievements so impressive as to obscure the warm, brilliant and occasionally difficult man we knew. The Times (March 16, 2010) called him a distinguished Roman historian, and this is unquestionably the most distinguished aspect of his career: he made immense contributions to his profession, especially as a historian, but also as an archaeologist.

Dept. of Archaeology and Classical Studies, Wilfrid Laurier University, Waterloo, Ont. (J.F.) Dept. of Art and Art History, Trinity University, San Antonio, TX (M.B.G.) 


\section{Carthage bibliography for C. M. Wells and the work of the Second Canadian Team}

(all solely by C. M. Wells unless stated otherwise)

1977. “Carthage 1976. La muraille théodosienne," EMC/CV 21, 15-23.

Jentel, M. O. 1977. "En marge des fouilles canadiennes à Carthage: quelques scènes des légendes d'Achille et d'Héraclès," Revue d'art canadienne 4, 36-39.

1978. "Canadian excavations at Carthage, Site 2: the Theodosian Wall," Current Anthropology 19, $390-91$.

Wells, C. M., L. Neuru \& R. Blockley 1978. "Carthage, site 2: the Theodosian Wall," EMC/CV 22, 9-12.

Wells, C. M. \& E. Wightman 1979. “Carthage 1978: la muraille théodosienne," EMC/CV 23, 15-18.

1980. "Carthage: the Late Roman defences," in W. S. Hanson \& L. J. F. Keppie (edd.), Roman frontier studies 1979:

Papers presented to the 12th Int. Congress of Roman Frontier Studies (BAR S71, Oxford) vol. 3, 999-1004.

Wightman, E. M. 1980. "The plan of Roman Carthage: practicalities and politics," in J. G. Pedley (ed.), New light on ancient Carthage (Ann Arbor, MI) 29-46 with figs.

1980. "The defense of Roman Carthage," ibid. 47-65 with figs.

Wells, C. M. \& E. M. Wightman 1980. "Canadian excavations at Carthage, 1976 and 1978: the Theodosian Wall, northern sector," JFA 7, 43-63.

Wells, C. M. \& E. M. Wightman 1980. "Carthage, morthern sector: the Theodosian Wall, 1979 excavations," EMC/CV 24, 11-18.

1980. "Canada II," CEDAC Carthage Bulletin 3, 12.

Neuru, L., D. Kyle, A. Demers \& J. W. Hayes 1980. "Late Roman pottery: a fifth-century deposit from Carthage," AntAfr 16, 195-211.

1981. "Excavations at Carthage, northern sector (2nd Canadian team): progress report, end of 1980 season," EMC/CV 25, 1-10.

1981. "Quelques remarques sur Carthage à la veille des invasions arabes," BCTH 17B, 55-63.

1981. "Bref rapport archéologique: Canada," CEDAC Carthage Bulletin 4, 14-18.

1982. "Excavations at Carthage, northern sector, 1981," EMC/CV 26, 206-13 with pls.

1982. "L'Afrique à la veille des invasions arabes," in id. (ed.), L'Afrique romaine (Les Conférences Vanier 1980; Ottawa) 87-105.

Neuru, L. 1982. "Un dépôt du cinquième siècle: quelques amphores," Actes du colloque sur la céramique antique de Carthage, 23-24 juin 1980 (CEDAC Dossier 1) 219-21.

1983. "Brefs rapports archéologiques. Canada II," CEDAC Carthage Bulletin 5, 13.

Ellis, S. 1985. "Carthage in the seventh century an expanding population?," in P. Senay (ed.), CEA $17=$ Actes du Congrès int. sur Carthage de l'Université du Québec à Trois-Rivières (Canada) 1984 (Carthage vol. 7; TroisRivières) 30-42.

Gallagher, J. B. 1985. "Mudbrick at Roman Carthage," ibid. 64-112.

Hayes, J. 1985. "Réflexions sur la verrerie des époques tardives à Carthage," ibid. 113-26.

Wells, C. M., J. B. Gallagher \& M. S. Goodfellow 1985. "Bref rapport archéologique: Canada II, 1982-1983," CEDAC Carthage Bulletin 6, 7-18.

Wightman, E. M. 1985. "Geological research and excavation in the northern sector of Carthage, June-July 1983," CEDAC Carthage Bulletin 6, 18-19.

Greene, J. A. 1985. "Canadian Carthage survey, 1983: preliminary report," CEDAC Carthage Bulletin 6, $19-21$.

Ellis, S. 1985. "Excavations in the Canadian sector (2CC9)," CEDAC Carthage Bulletin 6, 21-22.

Neuru, L. 1986. "Cooking wares of the Byzantine epoch at Carthage: some observations," in P. Senay (ed.), CEA $18=$ Actes du Congrès int. sur Carthage de l'Université du Québec à Trois-Rivières (Canada) 1984 (Carthage vol. 8; Trois-Rivières) 69-79.

Wells, C. M., J. Gallagher \& M. S. Goodfellow 1986. "Further light on the late defences at Carthage," in Studien zu den Militärgrenzen Roms, III. 13. Int. Limeskongress, Aalen 1983 (Stuttgart) 673-79.

Wells, C. M., J. Freed \& J. Gallagher 1988. "Houses of the Theodosian period at Carthage," EMC/CV 32, $195-210$.

1992. "Le mur de Théodose et le secteur nord-est de la ville romaine," in A. Ennabli (ed.), Pour sauver Carthage. Exploration et conservation de la cité punique, romaine et byzantine (Tunis) 115-24.

Garrison, M. B., P. W. Foss \& C. M. Wells 1993. "A newly discovered cryptoporticus and bath at Carthage," JRA 6, 251-60.

1996. "Paul Gauckler et la colline de l'Odéon à Carthage," Ktèma 21, 157-79.

Wells, C. M., M. Carroll, J. Freed \& D. Godden 1998. "The construction of decumanus VI N and the economy of the early colony of Carthage," in Carthage papers (JRA Suppl. 28) 7-63.

Wells, C. M. \& M. B. Garrison 1999. "A bath complex on the Odeon Hill at Carthage," in J. DeLaine \& D. E. Johnston (edd.), Roman baths and bathing, Part 2: Design and context (JRA Suppl. 37.2), 303-17.

2004-5. "A cuckoo in the nest: the Roman odeon at Carthage in its urban context," AJAH n.s. 3-4, 131-42.

Cf. also: 1982. "Recent excavations at Carthage: a review article," AJA 86 293-96 (= review of J. Humphrey [ed.], Excavations at Carthage conducted by the University of Michigan, vols. 2-4; P. Senay, Carthage, vols. 1-3 [= CEA 6, 9, 10]; and S. Lancel, Byrsa 1).

1985. "Edith Mary Wightman in memoriam," CEDAC Carthage Bulletin 6, 3-4.

1991. Review of J. Humphrey, The circus and a Byzantine cemetery at Carthage, in AJA 95, 564-66. 